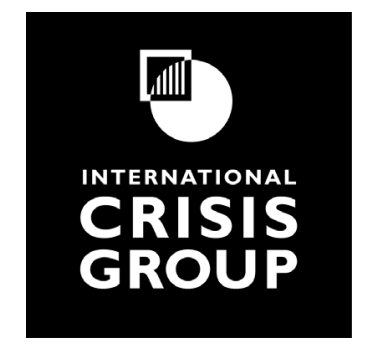

\title{
Countering Jihadist Militancy in Bangladesh
}

Asia Report N²95 | 28 February 2018 


\section{Table of Contents}

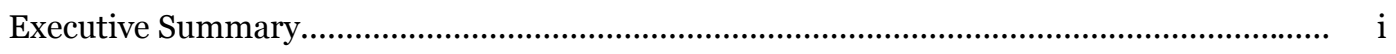

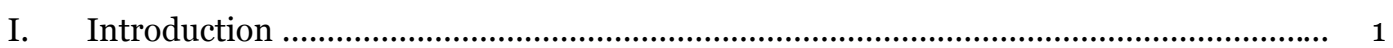

II. Genesis of Jihadist Militancy in Bangladesh .................................................... 2

III. Setting the Stage for a Jihadist Resurgence ........................................................

A. Politicised Justice and an Islamist Backlash ................................................. 5

B. Political Polarisation................................................................................. 6

IV. Today's Jihadist Landscape ............................................................................ 7

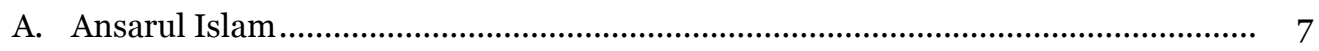

B. Jamaat-ul Mujahideen Bangladesh ................................................................. 8

C. "Neo-Jamaat-ul Mujahideen" and ISIS .......................................................... 10

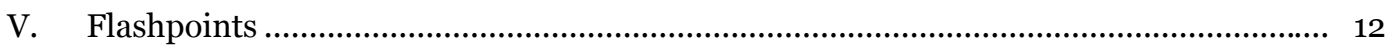

A. Resentment in the Military ........................................................................ 12

B. The Rohingya Crisis .................................................................................. 13

VI. The State's Response ....................................................................................... 15

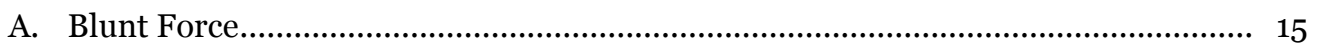

B. Following the Money .................................................................................. 17

C. Politicising Counter-terrorism.................................................................... 18

VII. Improving the Government's Response.................................................................. 20

A. Reforming the Criminal Justice System ........................................................ 20

B. Political Reconciliation and Democratic Debate................................................. 20

C. Curbing Recruitment: Engaging Bangladesh's Youth ........................................ 22

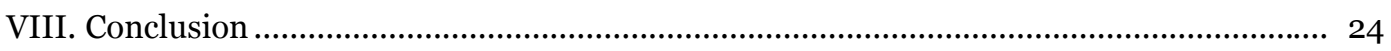

APPENDICES

A. Map of Bangladesh ....................................................................................... 25

B. About the International Crisis Group ................................................................... 26

C. Crisis Group Reports and Briefings on Asia since 2015 ......................................... 27

D. Crisis Group Board of Trustees .......................................................................... 28 


\section{Principal Findings}

What's new? Two groups, Jamaat-ul Mujahideen Bangladesh and Ansarul Islam, dominate Bangladesh's jihadist landscape today. Attacks since 2013 have targeted secular activists, intellectuals and foreigners, as well as religious and sectarian minorities. The ruling Awami League has politicised the threat; its crackdowns on rivals undermine efforts to disrupt jihadist recruitment and attacks.

Why did it happen? Bangladesh's antagonistic politics have played a part in enabling the jihadist resurgence. The state confronted groups responsible for an earlier wave of violence with some success from 2004 to 2008. Subsequently, especially since controversial January 2014 elections, bitter political divisions have reopened space for new forms of jihadist activism.

Why does it matter? A lull in violence over recent months may prove only a temporary respite. With elections approaching in December, politics could become even more toxic. The government's continued marginalisation of the opposition Bangladesh Nationalist Party, and its forcing underground of opponents like Jamaat-e-Islami, risk sapping resources from efforts to disrupt jihadists.

What should be done? Instead of relying on indiscriminate force, including alleged extrajudicial killings and enforced disappearances, the government should adopt a counter-terrorism strategy anchored in reformed criminal justice and better intelligence gathering. Rather than cracking down on rivals, it should forge a broad social and political consensus on how to confront the threat. 


\section{Executive Summary}

As Bangladesh's political polarisation reaches historic highs and local jihadist groups forge links with transnational movements, conditions are ripe for new forms of militancy that could threaten the country's security and religious tolerance. Two groups, Jamaat-ul Mujahideen Bangladesh (JMB) and Ansarul Islam, dominate today's jihadist landscape; a faction of the former appears to have consolidated links to the Islamic State (ISIS) while the latter is affiliated with al-Qaeda's South Asian branch. Both have perpetrated a string of attacks over the past few years, some targeting secular activists, others Bangladeshi minorities. The ruling Awami League has politicised the threat. Its crackdowns on political rivals sap resources from efforts to disrupt jihadist activities. Instead, it should invest in reinforcing the capability of the security forces and judiciary and build political consensus on how to tackle the threat.

The country's recent history of jihadism dates to the late 1990s, when veterans of the anti-Soviet struggle in Afghanistan returned to Bangladesh. A first wave of violence, involving two groups, the Harkat-ul Jihad al-Islami Bangladesh and the JMB, peaked on 17 August 2005, when the latter group synchronised bomb blasts in 63 of the country's 64 districts. Successive governments subsequently took action against the JMB's leadership, but the group has revived itself, albeit in a new form. Another group, Ansarul Islam (or Ansar), has also emerged, while a JMB splinter - dubbed the "neo-Jamaat-ul Mujahideen" by law enforcement agencies - calls itself the Islamic State-Bangladesh and has funnelled fighters into Iraq and Syria.

Ansar portrays itself as the defender of Islam from those who - in its leaders' view - explicitly attack the religion. The JMB, on the other hand, has named a longer list of enemies: it considers perceived symbols of the secular state and anyone not subscribing to its interpretation of Islam as legitimate targets. The Bangladesh police allege that JMB operatives have played a part in attacks claimed by ISIS on prominent members of minority communities and religious facilities and events, including Ahmadi mosques, Sufi shrines, Buddhist and Hindu temples, and Shia festivals. An attack on a Dhaka café on 1-2 July 2016 that killed over twenty people, mostly foreigners, appears to have involved loose cooperation between different groups, including both rural-based madrasa students and elite urban young men.

Bangladesh's contentious national politics have played a role in enabling the jihadist resurgence. Ansar found its initial raison d'être in the Awami League government's post-2010 trials of people accused of war crimes perpetrated in the 1971 war of independence. Those trials, targeting the senior leadership of the largest Islamist party Jamaat-e-Islami (JeI), prompted criticism for violating due process, lacking transparency, and involving intimidation and harassment of defence lawyers and witnesses. The prosecutions were used to crush the JeI, a close ally of the Awami League's main political rival, the Bangladesh Nationalist Party (BNP), and to discredit the BNP itself. They provoked widespread anger among Islamists, which was mostly expressed through mass protest, not jihadist violence. Yet Ansar, depicting the trials as an assault on Islam, recruited urban, educated youth, albeit in relatively small numbers, and perpetrated brutal attacks on secular activists and bloggers who had demanded harsh punishment for those prosecuted. 
Political polarisation has contributed to the growth of militancy in less direct ways, too. The marginalisation of the BNP through politically motivated corruption and other trials of its leadership, including party chief Khaleda Zia's 8 February 2018 conviction and five-year sentence for corruption, and of the JeI, through the war crimes trials and a ban on its participation in elections, have eliminated most democratic competition and encouraged the growth of a jihadist fringe. A purge of BNP and JeI sympathisers from the armed forces has elicited animosity within some military circles toward the Awami League, which the jihadists also appear to be seeking to exploit. The BNP, for its part, has on occasion used terrible violence, or supported groups that do so, fuelling political animus and deepening schisms.

The influx of hundreds of thousands of Rohingya Muslims from Myanmar's Rakhine state in August-December 2017 also raises security concerns for Bangladesh. Jihadist groups - including ISIS and Pakistani militants - have referenced the Rohingya's plight in efforts to mobilise support. For now, though, little suggests that the refugees are particularly susceptible to jihadist recruitment. Bangladesh's response to the humanitarian tragedy should focus primarily not on counter-terrorism but on providing support for refugees and redoubling efforts to assuage potential friction between them and host communities.

The state response to the surge of jihadist violence over the past few years has relied primarily on blunt and indiscriminate force, including alleged enforced disappearances and extrajudicial killings. Such tactics have eliminated large numbers of jihadists and weakened militant groups. But they undermine intelligence gathering. Security officials fear the ability of jihadist movements to recruit, raise funds and conduct operations remains intact. To make matters worse, Awami League leaders have exploited the threat to further discredit the BNP and JeI, accusing them of complicity in high-profile attacks. The government continues to use security forces to target its opponents, motivated, it appears, by the imperative of victory in the December 2018 general elections.

While the past year has seen a lull in attacks, marginalising the mainstream political opposition is likely to play into the hands of jihadist groups. Politicised, the police force and judiciary will continue to struggle with the detailed investigative work necessary to disrupt networks that now tap not only madrasa students and their families in deprived rural areas but also privileged students in wealthier quarters of the capital. While the Awami League appears little inclined to do so ahead of this year's vote, reversing the polarisation that creates an enabling environment for jihadists and building political consensus on how to tackle the problem, while investing in a professional police and judiciary, are likely prerequisites of forestalling further jihadist violence. Without a change of course - and particularly if the December elections trigger a crisis similar to that around previous polls - the country could face another jihadist resurgence.

Brussels, 28 February 2018 


\section{Countering Jihadist Militancy in Bangladesh}

\section{Introduction}

Bangladesh faces a sustained threat from jihadist attacks. ${ }^{1}$ Since 2015, two jihadist groups, Jamaat-ul Mujahideen Bangladesh (JMB) and Ansarul Islam (hereafter Ansar), have targeted foreigners, secular activists and intellectuals, religious and sectarian minorities, and other perceived opponents with rising frequency. ${ }^{2}$ These groups appear to be more integrated into transnational networks than earlier generations of jihadists. Yet their expansion is largely rooted in domestic political dynamics, which influence and inform state efforts against them.

The bloody 1-2 July 2016 siege at a café in Dhaka's upscale Gulshan neighbourhood, the heart of the diplomatic zone, forced domestic and international policymakers to reconsider the extent to which jihadist militancy had taken root in Bangladesh. That three out of five alleged attackers belonged to Dhaka's elite, not the madrasa sector more commonly associated with such jihadist militancy, suggests that the appeal of jihadism has spread and that jihadists may be able to tap a new constituency from which to recruit, even if thus far only in small numbers. ${ }^{3}$

The report analyses the roots of Bangladesh's jihadist groups, their goals, organisational dynamics, recruitment patterns and links to regional and transnational networks. It is based on interviews conducted in April-August 2017 with security officials, the legal community, and political and civil society actors, including representatives from Islamist parties and umbrella groups. Security risks inhibited access to jihadist groups and detainees; the report thus draws on their leaflets, online literature and public statements, and interviews with lawyers and law enforcement officials who have closely dealt with them. It proposes measures to counter the threat, based on analysis of the impact and effectiveness of the government's response. Given the topic's sensitivity, and an increasingly repressive environment in Bangladesh, most names have been withheld.

\footnotetext{
${ }^{1}$ For Crisis Group analysis of Bangladesh's political and security dynamics, see Asia Reports $\mathrm{N}^{\circ} \mathrm{s} 277$, Political Conflict, Extremism and Criminal Justice in Bangladesh, 11 April 2016; 264, Mapping Bangladesh's Political Crisis, 9 February 2015; 187, The Threat from Jamaat-ul Mujahideen Bangladesh, 1 March 2010; 182, Bangladesh: Getting Police Reform on Track, 11 December 2009; 151, Restoring Democracy in Bangladesh, 28 April 2008; and 121, Bangladesh Today, 23 October 2006.

2 "Ansar" in this case should not be confused with the Bangladesh Ansar, a volunteer paramilitary force under the home affairs ministry's authority.

3 For definitions of "jihadism" and "jihadist", see Crisis Group Special Report N ${ }^{\circ} 1$, Exploiting Disorder: al-Qaeda and the Islamic State, 14 March 2016, p. 2. This report uses these terms in accordance with Crisis Group practice; in Bangladesh, however, the preferred terms are "Islamic militancy" and "Islamic militant".
} 


\section{Genesis of Jihadist Militancy in Bangladesh}

Jihadist militancy in Bangladesh began in the 1980s, when around 3,000 Bangladeshis reportedly joined the U.S. and Saudi-sponsored anti-Soviet jihad in Afghanistan. ${ }^{4}$ A first generation of Bangladeshi militants were veterans of that war. In 1992, a new group, Harkat-ul Jihad al-Islami Bangladesh (also referred to as Harkat-ul Jihad), led by three Afghanistan veterans, Mufti Abdur Rouf, Mowlana Abdus Salam and Mufti Abdul Hannan Sheikh, declared that Bangladesh should become an Islamic state. ${ }^{5}$ The group, which operated from the Chittagong Hill Tracts bordering Myanmar, also aimed to aid the Rohingya Muslims in that country. ${ }^{6}$ A Harkat-ul Jihad leader, Fazlul Rahman, along with jihadist leaders from Pakistan and the Middle East, signed Osama bin Laden's 1998 fatwa calling for jihad against the U.S. and its allies. ${ }^{7}$ In 1999, the group claimed a failed assassination attempt on Bangladesh's leading poet, journalist and human rights activist Shamsur Rahman, and carried out a bomb attack at a cultural event in Jessore that killed ten people. ${ }^{8}$

After the 11 September 2001 attacks in the U.S., the group became more active under the leadership of Mufti Hannan, who had established strong links with Lashkar-e-Tayyaba in Pakistan. ${ }^{9}$ In February 2002, it attacked the American Center in Calcutta, killing four police constables and a security guard, and injuring over twenty in the first strike on a target in India. In May 2004, it attempted to assassinate the British high commissioner to Dhaka. Its deadliest action was the August 2004 grenade attack on an election rally of then opposition leader and chief of the secular Awami League party, Sheikh Hasina Wajed, killing over twenty people; scores, including Hasina herself, were injured. ${ }^{10}$ In addition to attacks in Sylhet Division, in the north east, and areas around Dhaka, the Harkat-ul Jihad also struck numerous times in southern locations such as Akhaura, Bagerhat and Khulna, mostly between 1999-2005. ${ }^{11}$

Founded in 1998, the JMB and its militant wing Jagrata Muslim Janata Bangladesh became active in the early 200os, recruiting and training, raising funds, running outreach programs, and mobilising members across the north and in selected southern districts such as Chittagong, Jessore and Khulna. Its Dhaka-based leader

\footnotetext{
${ }^{4}$ Riaz Ali, Islamist Militancy in Bangladesh: A Complex Web (London, 2008).

${ }^{5}$ All three had reportedly fought under Taliban leader Mullah Mohammad Omar. Zayadul Ahsan and Pavitra Banavar, "Who are the militants?”, in Ali Riaz and C. Christine Fair (eds.), Political Islam and Governance in Bangladesh (Oxford, 2011), pp. 71-90.

${ }^{6}$ For more on ties between Harkat-ul Jihad and the Myanmar insurgent group Rohingya Solidarity Organisation, see "How Southeast Asian and Bangladeshi extremism intersect", Institute for Policy Analysis of Conflict, No. 37, 8 May 2017.

${ }^{7}$ Lawrence Wright, The Looming Tower: Al-Qaeda's Road to 9/11 (London, 2006).

8 "Huji attacked poet Shamsur in '99", The Daily Star, 30 November 2007; "Udichi observes Jessore tragedy day in city”, New Age, 7 March 2016.

${ }^{9}$ Crisis Group interview, senior retired military officer, Dhaka, June 2017.

10 "3 HuJI activists held in Gujarat for Kolkata attack", The Times of India, 16 February 2002; "British diplomat hurt in Bangladesh bombing”, The Telegraph, 21 May 2004.

${ }^{11}$ Home ministry's internal report on militant organisations, provided to Crisis Group, June 2017.
} 
Abdur Rahman also began establishing links with political powerbrokers willing to support his agenda. ${ }^{12}$

Jagrata itself began as a vigilante group in north-eastern regions that had been the base of left-wing militants for decades. Khaleda Zia's BNP-led government (20012006) initially failed to take action against it, due to limited law enforcement capacity but also sympathy for these groups within Jamaat-e-Islami (JeI), Bangladesh's largest Islamist party and a member of the BNP's governing alliance. ${ }^{13}$ The animosity of the military and some BNP leaders toward India also drove them to patronise various Islamist groups supporting insurgencies in India's north-eastern provinces and Myanmar's Rakhine state. ${ }^{14}$ Some government and police officials saw the JMB and Jagrata as useful tools against left-wing militants. ${ }^{15}$ Despite these reservations, domestic and international pressure nudged the government to form, in 2004, an elite paramilitary anti-crime and anti-terrorism unit, the Rapid Action Battalion, which includes military and police personnel.

JMB's 17 August 2005 countrywide coordinated and simultaneous attacks, involving over 459 low-intensity bombs, in all but one of Bangladesh's 64 districts, killing two people and injuring around 100, proved a turning point. ${ }^{16}$ The subsequent security crackdown, including trials and executions of top JMB members, forced the group into hiding. In the following years, its leaders described the synchronised 2005 attack as a "sound blast" to draw attention to their message, contained in leaflets left at the bombing sites, which called for war against "Western imperial powers" and their local allies, including Bangladesh's secular state. The judicial system was a particular target; there were several attacks on judges and court premises. ${ }^{17}$

While JMB and Harkat-ul Jihad represented similar threats, and often operated in tandem, violently opposing Bangladesh's secular traditions, there were fundamental differences. Harkat-ul Jihad drew on South Asian Islamic traditions, its ideological bent close to that of today's Deobandi-inspired Hefazat-e-Islam, a hardline Islamist movement which over recent years has won concessions from the ruling party (see Section VII.B). Harkat-ul Jihad was largely based in the south, and it found its recruits in qaumi (privately run) madrasas. JMB, on the other hand, drew on the Wahhabi-inspired Ahl-e Hadith movement and was located mainly in the north east, though it also conducted outreach and recruitment drives in the south west, in Satkhira and Bagerhat districts. ${ }^{18}$

\footnotetext{
${ }^{12}$ Crisis Group Report, The Threat from Jamaat-ul Mujahideen Bangladesh, op. cit.

${ }^{13}$ Crisis Group Report, Political Conflict, Extremism and Criminal Justice in Bangladesh, op. cit.

${ }^{14}$ Ibid.

${ }^{15}$ Officials involved in counter-terrorism efforts at the time confirmed that some members of the coalition government had actively promoted the militants, while police backed their anti-left operations. Crisis Group interviews, security officials and analysts, Dhaka, May-June 2017. Also see Crisis Group Report, The Threat from Jamaat-ul Mujahideen Bangladesh, op. cit.

16 " 459 blasts in 63 districts in 30 minutes, 2 killed, 100 injured; all explosions were time bombs; Jamaat-ul Mujahideen leaflets found”, The Daily Star, 18 August 2005; "Bombs explode across Bangladesh”, BBC News, 17 August 2005.

${ }^{17}$ Crisis Group Report, The Threat from Jamaat-ul Mujahideen, op. cit.

${ }^{18}$ Crisis Group interview, Shakhawat Hossain, Ahl-e Hadith Andolon Bangladesh spokesperson, Rajshahi, June 2017. The group claimed as its lineage, and the inspiration for its name, Islamist groups that had fought British colonialism in the early 19th century. Its base, in the north east, has
} 
Increasingly bitter competition between the Awami League and BNP ahead of elections scheduled for January 2007 led to paralysing street violence and a political crisis, prompting a coup and military rule, between 2006 and 2008, behind the veneer of a caretaker government. ${ }^{19}$ The military jailed much of the political class. The military-backed government redoubled counter-terrorism efforts, including through specialised trainings for law enforcement officials and anti-militancy messaging in the media and the state-run Islamic Foundation, as well as through Friday sermons in mosques across the country. ${ }^{20}$ It also tried some JMB leaders. Arrests and convictions of JMB and Harkat-ul Jihad members continued after the restoration of democracy and elections in December 2008, which returned the Awami League to office. ${ }^{21}$ By that time, the jihadist leadership appeared to have been dismantled and the security environment seemed much improved, leading law enforcement agencies to shift attention away from militant groups.

also been the seat of the Ahl-e Hadith movement since 1994, when a former Rajshahi university professor, Asadullah Ghalib, formed an organisation he called Ahl-e Al Hadith.

${ }^{19}$ Following the bloody civil war that led to Bangladesh's independence in 1971, the Awami League, led by Sheikh Mujib ur Rahman, formed the first government. In 1972, it enacted a constitution that, like the party's founding ideology, drew on the principles of democracy, nationalism, socialism and secularism. Mujib and most of his family were killed by army personnel in the 15 August 1975 coup. His daughter, Sheikh Hasina Wajed, took over the leadership and remains the head of the Awami League. BNP leader Khaleda Zia is the wife of Bangladesh's first military ruler, Major General Ziaur (Zia) Rahman (1977-1981), who created the party as a civilian proxy and alternative to the secular Awami League. Crisis Group Report, Mapping Bangladesh's Political Crisis, op. cit.

${ }^{20}$ The Bangladesh Islamic Foundation is a state-run organisation that supports research and scholarship on Islam and dissemination of "Islamic values". "Combating extremism: Still relying mostly on force”, The Daily Star, 30 June 2017.

${ }^{21}$ Crisis Group Report, Mapping Bangladesh's Political Crisis, op. cit. 


\section{Setting the Stage for a Jihadist Resurgence}

\section{A. Politicised Justice and an Islamist Backlash}

The Awami League came to power in January 2009 having promised an international war crimes tribunal to prosecute those responsible for atrocities during the 1971 war of independence, a longstanding demand popular with the party's voter base. Most of those expected to be tried were JeI members; others were from the BNP. The tribunal was established in 2010.

While the quest for justice was legitimate, the trials were deeply flawed, lacking due process. They were also convenient tools for sidelining or eliminating rivals and rallying the Awami League's political base. The convictions and executions that followed provoked a domestic backlash; many of the accused had major followings, notably among religiously conservative constituencies across the country. In particular, the 2013 death sentence for JeI leader Delwar Hossain Sayedee, a popular preacher, prompted violent countrywide demonstrations and clashes with police that left hundreds of protesters dead. Islamists portrayed the trials as an attack on Bangladesh's Muslim identity. ${ }^{22}$

Secular activists mobilised, too, though to insist on harsher sentences. In February 2013, after another JeI leader, Abdul Quader Mollah, was given life imprisonment, activists demonstrated in Dhaka's Shahbagh square demanding a death sentence. ${ }^{23}$ These protests, dubbed the Shahbagh movement, were led by urban, secular youth, including bloggers critical of the role of organised religion in Bangladesh's secular polity. Islamists highlighted these opinions to discredit the movement as anti-Islam, demanding that Shahbagh organisers be punished. ${ }^{24}$

The war crimes trials and the Shahbagh movement provided the backdrop for a new era of Islamist and jihadist activism. By 2013, JeI was on the defensive, with most of its top leaders on trial. Hefazat-e-Islam, a hitherto marginal umbrella organisation sustained by qaumi (privately run) madrasas, stepped into the gap, quickly becoming a prominent socio-political force by channelling Islamist sentiment against the trials in large street demonstrations in late 2013. To defuse the protests, the government made concessions, including withdrawing plans to regulate the qaumi madrasa sector. ${ }^{25}$ Hefazat also allegedly delivered the government a list of 84 bloggers and activists it wanted prosecuted and executed for making derogatory statements about Islam. ${ }^{26}$

A new kind of jihadist mobilisation surfaced shortly thereafter. On 15 February 2013, ten days after the Shahbagh demonstrations began, prominent blogger Ahmed Rajib Haider, whose writings had in part inspired those demonstrations, was brutally

\footnotetext{
${ }^{22}$ Crisis Group Report, Mapping Bangladesh's Political Crisis, op. cit.

${ }^{23}$ In response, the government repealed a law that prohibited appeals of war crimes trial verdicts. The high court resentenced Mollah, this time to death, in September 2013.

${ }^{24}$ Crisis Group Report, Mapping Bangladesh's Political Crisis, op. cit.

${ }^{25}$ Ibid. See also "Bangladesh's radical Muslims uniting behind Hefazat-e-Islam”, The Guardian, 30 July 2013.

${ }^{26}$ Amid the killings of bloggers, Hefazat officially denied association with this list. "Hefazat has no list of bloggers", Prothom Alo, 25 May 2015.
} 
murdered outside his home in Dhaka. ${ }^{27}$ A new group, the Ansarullah Bangla Team (later renamed Ansarul Islam), an affiliate of al-Qaeda, claimed responsibility. The following month, the group gave a thirteen-point list of demands to the government, including for a blasphemy law to try secular bloggers, marking a convergence in aspects of its agenda - though not its methods - with Hefazat. ${ }^{28}$

\section{B. Political Polarisation}

In addition to the flawed trials, Bangladesh's deeply polarised politics and the increasingly exclusionary bent of the Awami League-led government have contributed to the resurgence of militancy. In mid-2013, the Bangladeshi high court banned JeI from contesting forthcoming parliamentary elections on the grounds that an Islamist party running violated the secular constitution. Even if not a political ruling, this ban served to undercut a critical ally of the Awami League's main rival, the BNP. It also led the JeI to resort to violence ahead of the January 2014 vote. As elections approached, the government pushed ahead with preparations despite the BNP's objections; in the end, the BNP announced the day before the polls that it would boycott. Law enforcement agencies focused attention on opposition leaders and activists spearheading violent protests to subvert the election. ${ }^{29}$

By the end of 2013, at least 500 people had been killed, making it the deadliest year of civil strife since Bangladesh's secession from Pakistan in 1971. The polls themselves, in January 2014, were likewise marred by violence. Given the BNP's boycott, Bangladesh's parliament is almost bereft of opposition to the ruling party. A year later, a very violent campaign led by the BNP and JeI - replete with arson attacks on polling stations and assaults on policemen, as well as hartals (strikes) and transport blockades - marked the anniversary of those elections. This campaign, aimed at forcing fresh elections, provoked months of clashes, leaving around 150 people dead or missing. JeI activists were responsible for some of the worst attacks. ${ }^{30}$

The BNP's marginalisation from mainstream politics - part self-inflicted through its boycott and violent tactics; part due to the government's rejection of its demands for electoral reforms - together with the government's targeting of the JeI through the war crimes trials and electoral ban, created a major political vacuum. As law enforcement agencies focused on containing the Awami League's political opponents, they failed to effectively counter the emergence of the Ansarul Islam and the reemergence, starting around mid-2014, of the JMB, which still had a nationwide network of members recruited from qaumi madrasas, informants and sympathisers.

\footnotetext{
${ }^{27}$ Another prominent blogger Asif Mohiuddin survived a similar attack by militants a few weeks before the protests began.

28 "Hefazat demands", The Daily Star, 6 April 2013.

${ }^{29}$ These actions included countrywide hartals (strikes), demonstrations and traffic blockades that stalled economic activity and travel outside the urban centres. Awami League supporters and officials were also attacked in the run-up to and on election day. "Democracy in the crossfire: Opposition violence and government abuses in the 2014 pre- and post-election period in Bangladesh", Human Rights Watch, April 2014.

${ }^{30}$ Crisis Group Report, Mapping Bangladesh's Political Crisis, op. cit.
} 


\section{Today's Jihadist Landscape}

\section{A. Ansarul Islam}

What had started as an online community reportedly inspired by the sermons of Anwar al-Awlaki, a U.S. citizen who joined al-Qaeda's Yemen branch, al-Qaeda in the Arabian peninsula, gradually morphed into a group of young Bangladeshis following a fiery local preacher, Jashimuddin Rahmani, based in Dhaka's Basila neighbourhood. ${ }^{31}$ Ansar soon began identifying itself, through online posts, as the Bangladesh chapter of al-Qaeda. ${ }^{32}$

Beginning in 2013, Ansar prioritised killing liberal and secular bloggers, many of whom were reportedly on the Hefazat's alleged list of 84 activists. ${ }^{33}$ In an online statement, Ansar said it was targeting writers, journalists, intellectuals and artists who publicly insulted Islam, rather than unbelievers who kept their views private. ${ }^{34}$ In February 2015, Avijit Roy, a prominent U.S.-based blogger visiting Dhaka, was killed by machete-wielding assailants at a major book fair. In the course of the year, six more bloggers and two gay rights activists were similarly hacked to death, and four others injured, either in their homes or in public places, with all attacks claimed by Ansar. ${ }^{35}$

Ansar is primarily urban-based. A well-informed source said many members do not know each other except through pseudonyms. ${ }^{36}$ Although it remains a small organisation, according to intelligence and counter-terrorism officials, Ansar has a formal structure that divides members into three groups, managed by a coordination team: dawa, which oversees logistics and recruitment; asqari, which oversees military training; and a media wing run by IT experts that collates domestic and international coverage of the group. ${ }^{37}$ The group also includes a sub-group, mashul, which plans and oversees all attacks, while the foot soldiers executing operations are part of a subcategory called mamur. ${ }^{38}$

Many of Ansar's leaders and members appear to be well educated and Dhakabased. Rezwanul Azad Rana, a former activist from Shibir, the youth wing of the JeI, and a teaching assistant at North South, Dhaka's largest private university, was reportedly one of the group's first organisers and allegedly planned and oversaw the bloggers' murders, before fleeing to Malaysia after law enforcement agencies learned

\footnotetext{
${ }^{31}$ Rahmani, currently serving a five-year sentence for the murder of blogger Rajib, appears to have come into contact with many future Ansar organisers, including the primary men accused in the murder of Rajib, Rezwanul Azad Rana and Junoon Shikder, while serving as a cleric at a Dhaka mosque. Crisis Group interviews, counter-terrorism officials, Dhaka, May-June 2017.

32 “Ansarullah Bangla team reorganised as Ansar-ul-Islam”, Protom Alo, 10 April 2016.

33 "Fourth blogger hacked to death in Bangladesh", The Wall Street Journal, 7 August 2015.

34 "Ansar al-Islam Bangladesh lists categories of potential targets for killing", SITE Intelligence Group, 29 May 2015: https://news.siteintelgroup.com/Jihadist-News/ansar-al-islam-bangladeshlists-categories-of-potential-targets-for-killing.html.

35 "Behind killings in Bangladesh lies a brutal power struggle", The Indian Express, 29 April 2016.

${ }^{36}$ Crisis Group interview, Dhaka, June 2017.

${ }^{37}$ Crisis Group interviews, intelligence and counter-terrorism officials, Dhaka, June 2017.

${ }^{38}$ Crisis Group interview, well-informed source, Dhaka, June 2017.
} 
of his role. ${ }^{39}$ Other members kept Ansar's organisation intact and active after Rana's departure. One was reportedly Junoon Shikder, another North South student, arrested in 2013 for alleged links with Ansar but released on bail a year later. He, too, fled to Malaysia, in 2014, whence he reportedly moved to Syria, suggesting he may have shifted his allegiance from al-Qaeda to ISIS.

Since late 2015, the killings of bloggers have stopped. Many prominent online activists either have fled Bangladesh or keep a lower profile. ${ }^{40}$ Ansar itself appears to have faded from public attention, its appeal perhaps diminished in part because it arose in the context of the war crimes trials. With most high-profile Islamists accused of atrocities in 1971 convicted and some executed, the trials generate less immediate attention from the constituencies they initially outraged. Still, some security officials believe that Ansar and what the government calls the "neo-Jamaat-ul Mujahideen" (discussed below) work closely together, contributing some of the 40 Bangladeshis who reportedly travelled to join ISIS in Syria. ${ }^{41}$

Junoon and an unspecified number of other jihadists allegedly continue to operate Malaysia- and Singapore-based cells, which have been key to the transition of some Ansar members to ISIS, as well as to the facilitation of movement to Syria. ${ }^{42}$ Three of the five alleged attackers in the 2016 Dhaka attack reportedly had operated in Ansar's Malaysia cells for various durations, while four others, who were indirectly involved, had also spent time in that country. ${ }^{43}$ Intelligence officials claim to regularly discover communications between jihadists in Bangladesh and Malaysia- or Singapore-based Ansar cells during investigations. ${ }^{44}$ Ansar's current threat level is difficult to gauge, given that the organisation seems to be moving on from its original raison d'être, the war crimes trials, to a broader agenda.

\section{B. Jamaat-ul Mujahideen Bangladesh}

There were initially clear distinctions between Ansar and JMB. Ansar members saw themselves primarily as defenders of Islam battling Western secular ideas, rather than fighting for an Islamic state. The group's targets were limited to those it considered to have insulted the faith. Most Ansar leaflets that investigators recovered at

\footnotetext{
${ }^{39}$ Security officials said they first learned about Rana from U.S. intelligence contacts who had obtained information about him from a former North South student who is now serving a 30-year term in a U.S. federal prison. Crisis Group interviews, security officials, Dhaka, May-June 2017. See also "Blogger Rajib killing: convicted Rana hiding in Malaysia", The New Age, 22 January 2016; "Blogger Rajib murder mastermind arrested", Dhaka Tribune, 20 February 2017; Sajjan Gohel, "The nexus of local and international extremist groups in Bangladesh", South Asia@LSC blog, 22 July 2016.

40 "Living in fear away from home", The Hindu, 17 May 2016. Investigators and prosecutors have made little progress on the cases of the bloggers' killings.

${ }^{41}$ Crisis Group interviews, counter-terrorism officials, Dhaka, May-June 2017.

42 "How Southeast Asian and Bangladeshi extremism intersect", Institute for Policy Analysis of Conflict, Report No. 37, 8 May 2017.

43 Ibid.

${ }^{44}$ Crisis Group interviews, security officials, Dhaka, May-June 2017. See also "Singapore says arrests 27 Bangladeshi Islamists, deports 26", Reuters, 20 January 2016.
} 
attack sites emphasised that the organisation was not at war with peoples of other faiths unless they slighted or undermined Islam. ${ }^{45}$

In contrast, JMB since its founding almost two decades ago, and again in its recent resurgence, has pursued the establishment of Islamic law and perceived anyone not subscribing to its interpretation of Islam, including religious and sectarian minorities, as well as non-Muslim foreigners, as legitimate prey. Thus, while Ansar targeted only individuals such as Bangladeshi secular and liberal bloggers, JMB, both as a whole and, later, a faction more closely identified with ISIS (discussed below), focused on Bangladesh's minority communities, attacking Ahmadi mosques, Sufi shrines, Buddhist and Hindu temples, and Shia festivals, as well as prominent members of these communities. While ISIS claimed some of these attacks, police suspect a JMB role in executing them. ${ }^{46}$ Since 2015, JMB has expanded its activities beyond its traditional strongholds in the north and south west, and conducted attacks countrywide, including in Dhaka, where it was responsible - at least partly though perhaps entirely - for the 2016 attack.

At the outset, the outfit had four tiers, each defined by level of responsibility and commitment to the organisation: majlis-e-shura, a consultative decision-making council directly under the amir, or chief; ehsar, or full-time members; gayeri ehsar, or part-time activists; and sudhis (well-wishers) and saathis (comrades). In principle, JMB's organisational structure included a military wing, comprised entirely of ehsar (the other sections made up the non-military wing). This wing was meant to include six divisions, each with a chief and deputy, and four sectors - ordnance, operations, intelligence and medical - but it was never fully operationalised. Each sector was also meant to have subdivisions. For example, explosives, electronics technology, weapons collection and stockpiling fell under ordnance; guerrillas and fedayeen (suicide attackers) under operations. ${ }^{47}$

Today, the majlis-e-shura reportedly has seven members. It approves all attacks and killings. The current amir, Salauddin, oversees regional commanders and brigades, which have both dawa, or logistics and recruitment, and military wings. ${ }^{48} \mathrm{In}$ a recent interview, Salauddin said the group was expanding its network beyond Bangladesh, although it is difficult to assess the veracity of this claim; despite ties to militants elsewhere, the JMB itself has never perpetrated an attack outside Bangladesh. ${ }^{49}$

According to counter-terrorism officials, the group recruits not just young men, but entire families, including women. ${ }^{50}$ They claim that recruiters also are attempting to attract youth in regions outside Dhaka that are politically volatile and have a

45 "Ansar al-Islam Bangladesh lists categories of potential targets for killing”, SITE Intelligence Group, 29 May 2015: https://news.siteintelgroup.com/Jihadist-News/ansar-al-islam-bangladeshlists-categories-of-potential-targets-for-killing.html.

46 “Tavella shot dead by 'Neo-JMB'”, The Daily Star, 22 October 2016.

${ }^{47}$ Crisis Group Report, The Threat from Jamaat-ul Mujahideen, op. cit.

${ }^{48}$ Crisis Group interviews, counter-terrorism and intelligence officials, Dhaka, June 2017.

49 “Jamaatul Mujahideen amir Shaikh Salahuddin - special interview”, Sahm Al Hind Media, 13 May 2017.

${ }^{50}$ Several JMB hideouts raided in March and April 2017 were homes where most household members were allegedly involved in jihadist militancy in some capacity. The group has recruited entire families since its early days. "The family network of militants", Samakal, 14 August 2016. See also Crisis Group Report, The Threat from Jamaat-ul Mujahideen, op. cit. 
large conservative base, including the Chittagong Hill Tracts, Noakhali, Lakshmipur and Chapainababganj. ${ }^{51}$

\section{C. "Neo-Jamaat-ul Mujahideen" and ISIS}

Since the 2016 Dhaka attack, law enforcement officials began using the term "neoJamaat-ul Mujahideen". Some analysts argue they use this term to obscure ISIS's role in Bangladesh, and that many ISIS members are described by security officials as "neo-Jamaat-ul Mujahideen". ${ }^{2}$ In an interview, JMB's current amir, Salahuddin, dismissed the term as an invention of "infidels". He did, however, acknowledge that some members had joined ISIS. ${ }^{53}$

The "neo-Jamaat-ul Mujahideen" faction - which refers to itself as Islamic State Bangladesh - was thought to be led by a Canadian-Bangladeshi, Tamim Chowdhury, until his August 2016 death in an alleged extrajudicial killing. The faction was divided by geographic region, with each regional unit led by a commander who focused on operational activities endorsed by the central leadership. Several regional commanders have been killed in Dhaka, Chittagong, Rajshahi and points further north. The structure that Chowdhury headed appears to have been dismantled but counterterrorism officials say it has splintered into smaller cells that, for now, conduct fewer coordinated operations. ${ }^{54}$

In the run-up to the 2016 Dhaka attack, Chowdhury reportedly played a pivotal role in bringing together Ansar, a section of JMB's network still active in northern districts and the south east, and individuals acting on behalf of ISIS in Bangladesh and Syria. Counter-terrorism officials believe he was the primary coordinator between ISIS and Bangladeshi jihadist groups. ${ }^{55}$ Chowdhury concentrated his recruitment efforts in Dhaka's Banani neighbourhood and cantonment area, possibly tapping into discontent inside the army (discussed below). He also established contact with young extremists who provided access to youth studying at coaching centres. ${ }^{56}$ Many suspected militants detained or killed in security raids since July 2016 were young boys from affluent backgrounds who had months earlier left home; the "neo-Jamaatul Mujahideen" appears to be mining a similar demographic to Ansar, in other words. ${ }^{57}$

Even earlier, in 2015, Bangladeshi intelligence and security agencies uncovered communications between local jihadists and Bangladeshi fighters in Syria, though they could not decode much of the content. In a Chittagong raid, officials also discovered an ISIS flag and evidence of communication among JMB members arguing in favour of joining ISIS. ${ }^{8}$ ISIS also began claiming responsibility for several attacks

\footnotetext{
${ }^{51}$ Crisis Group interviews, security officials, Dhaka and Chittagong, May-June 2017.

${ }^{2}$ Crisis Group interviews, security analysts and journalists, Dhaka, May 2017.

53 “Jamaatul Mujahideen amir Shaikh Salahuddin - special interview”, Sahm Al Hind Media, 13 May 2017; "Living in fear away from home", The Hindu, 17 May 2016.

${ }^{54}$ Crisis Group interviews, counter-terrorism, intelligence officials, Dhaka, June 2017.

55 Crisis Group interviews, security officials, Dhaka, June 2017.

${ }^{56}$ These are informal evening schools at private residences or rented school premises, where teachers give private tutorials mostly to $\mathrm{O}$ and A level students. Crisis Group interview, senior intelligence official, Dhaka, June 2017.

57 “Where have the rest of the missing people gone?”, Dhaka Tribune, 4 April 2017.

${ }^{58}$ Crisis Group interviews, counter-terrorism officials, Dhaka, Chittagong, June 2017.
} 
in Bangladesh - including the 2016 Dhaka attack - on social media. The October 2015 issue of Dabiq, ISIS's monthly magazine, contained a special story on Bangladesh, praising earlier JMB exploits. Saifullah Ozaki, a Bangladeshi who formerly was an associate professor in Kyoto, reportedly played a key role through an online platform in recruiting Bangladeshis to ISIS and arranging their travel to Syria. There have been claims he may today even be the leader of the JMB faction - the "neoJamaat-ul Mujahideen" - that is more closely identified with ISIS. ${ }^{99}$

According to Bangladeshi counter-terrorism officials, local jihadists began using ISIS propaganda to appeal to middle- and upper middle-class youth, and inducting former activists from Hizb-ut Tahrir, a pan-Islamist missionary movement that rejects jihadist violence, and retired military personnel. ${ }^{60}$ By the time of the 2016 Dhaka attack, some Ansar and JMB elements appear to have also formally pledged allegiance to the leader of ISIS, Abu Bakr al-Baghdadi. ${ }^{61}$

Many security and counter-terrorism experts believe that a new generation of jihadists, earlier linked to JMB or Ansar, now identifies more directly with ISIS than with purely homegrown entities. ${ }^{62}$ The government, however, refuses to acknowledge an ISIS presence in Bangladesh. Some police officials contend that acknowledgment of such a presence would be too politically costly at a time when the government claims counter-terrorism successes. ${ }^{63}$

\footnotetext{
59 “How JMB evolved to 'Neo JMB”, BDNews24.com, 17 August 2016; "Islamic State claims they now have a regional commander in Bangladesh", BDNews24.com, 23 November 2015; "Bangladeshi who taught at Ritsumeikan among 10 suspects wanted by police over Dhaka attack: sources", The Japan Times, 21 July 2016.

${ }^{60}$ Crisis Group interview, counter-terrorism official, directorate general of forces intelligence, Dhaka, June 2017. Hizb-ut Tahrir is a transnational Islamist proselytising organisation that is banned in Bangladesh.

61 "Glimpses into 'jihadi' minds", The Daily Star, 2 August 2016.

${ }^{62}$ Crisis Group interviews, law enforcement and counter-terrorism officials, Dhaka, May-June 2017.

${ }^{63}$ Crisis Group interviews, senior police and other security officials, Dhaka, Chittagong, April-June 2017.
} 


\section{Flashpoints}

\section{A. Resentment in the Military}

Soon after it assumed office in 2009, the Awami League faced a mutiny by personnel from the Bangladesh Rifles, a border security force. Around 74 people were killed, including senior counter-terror officials and 57 army officers. The consequences of the insurrection, including a subsequent shakeup that saw several officers removed or reassigned, continue to reverberate within an institution that has held the levers of political power for seventeen of Bangladesh's 46 years as a state. ${ }^{64}$

In November 2009, five serving and six former army officers were detained in the attempted murder of Prime Minister Sheikh Hasina's nephew, Awami League parliamentarian Sheikh Fazle Noor Taposh. In January 2012, the army detained twelve officers for an alleged coup attempt. Although none was tried, most were dismissed on various grounds, most often indiscipline. Estimates of the number of officers sacked or forced into retirement since 2009 vary from 50 to $250 .{ }^{65}$ Many former officers, and even an adviser to Hasina at that time, believe the Bangladesh Rifles mutiny was used as a pretext by the Awami League government to restructure the army and purge it of more conservative pro-JeI and BNP elements that oppose the Awami League's secularism. ${ }^{66}$

To quell further dissent and unrest among officers and soldiers, the government offers financial incentives: salary hikes, budget increases and lucrative government contracts to military-controlled entities involved in housing, transport and major infrastructure projects. ${ }^{67}$ While these concessions may have yielded a less interventionist military in the short term, the aftereffects of the mutiny and the subsequent purges, which one former general officer described as "both a physical and psychological scar", may have pushed a small number of his colleagues toward jihadism. ${ }^{68}$

One of the officers implicated in the 2012 attempted coup, Major Syed Ziaul Hoque, reportedly became Ansar's military commander. ${ }^{69}$ Several young men living in residential quarters for former army officers were arrested in 2015 for attempting to establish ties to ISIS. ${ }^{70}$ The same year, a counter-terrorism official claimed that law enforcement officials had found military training manuals and military-issued

\footnotetext{
${ }^{64}$ In November 2013, a special court, trying 850 persons, including 23 civilians, for involvement in the 33-hour coup attempt, condemned 152 to death and 162 to life imprisonment. " 8 years on, gruesome BRD mutiny still in memory", Dhaka Tribune, 25 February 2017; "Real cause of BDR mutiny still a mystery”, Dhaka Tribune, 25 February 2014; "Death to 152 in Bangladesh Rifles mutiny case”, The Hindu, 5 November 2013.

65 "Bangladesh military foils coup plot”, The Guardian, 19 January 2012; “The armed forces in four years of alliance rule: 197 dismissed, 161 left job”, Prothom Alo, 26 May 2013.

${ }^{66}$ Crisis Group interviews, former army officers, Dhaka, June-July 2017. See also Crisis Group Report, Mapping Bangladesh's Political Crisis, op. cit.

67 "Project areas includes flood zone", The Daily Star, 29 October 2010; Crisis Group Report, Mapping Bangladesh's Political Crisis, op. cit.

${ }^{68}$ Crisis Group interview, senior former army officer, August 2017.

69 "Homegrown militants and ex-major behind Bangladesh attacks, police say", Reuters, 30 June 2016.

${ }^{70}$ Crisis Group interview, official, Counter Terrorism and Transnational Crime Unit (CTTC), Chittagong, June 2017.
} 
uniforms and bullets during a 2015 raid of a jihadist hideout in Chittagong. ${ }^{71}$ Jihadist organisations are clearly trying to tap into military disgruntlement.

\section{B. The Rohingya Crisis}

Much as discontent in the military provides opportunities that jihadists might exploit, so too could the Rohingya crisis. ${ }^{72} \mathrm{~A}$ brutal military campaign against the Rohingya in late 2017, following an attack on security personnel by the militant group, Arakan Rohingya Salvation Army (ARSA, also called Harakah al-Yaqin) in the north of Myanmar's Rakhine state, forced close to 700,00o Rohingyas to flee to Bangladesh. ${ }^{73}$ The Awami League government's response has included confinement of Rohingyas to camps in border regions and diplomacy aimed at ensuring the refugees' return, including through a late November repatriation agreement. Such efforts appear unlikely to bear fruit, given the Myanmar authorities' uncompromising stance and because conditions in Rakhine state are not conducive to refugees returning in a safe and sustainable manner. ${ }^{74}$

The Rohingya influx has significant security ramifications for Bangladesh, though the challenge for Bangladeshi authorities is to assess the dangers accurately and adopt a measured and sensible response. A large, stateless population with slim prospects of returning to Myanmar any time soon places enormous strain on authorities and host communities, raising the potential for friction between refugees and the local population.

That said, clearly it would be counterproductive - even offensive - to portray the long-suffering Rohingya community, for many of whom the past few months have brought unimaginable horrors, as jihadists in waiting. Some reports suggest that a small number from the refugee camps have joined the ARSA, though that group remains focused on Myanmar; as yet no evidence suggests it has ties to transnational jihadism..$^{75}$ In the past, militant Rohingya groups had small bases in Bangladeshi territories and one, the Rohingya Solidarity Organisation, collaborated with Jamaat-ul Mujahideen on weapons and explosives training; and some counter-terrorism analysts believe that Ansar might be training and arming Rohingya militants today. ${ }^{76}$

\footnotetext{
71 “Arrested youth, Galib, planned to set up Islamic State like organization in Bangladesh”, Ittefaq, 31 May 2015; Crisis Group interview, CTTC official, Chittagong, June 2017.

72 "Bangladesh says to meet with Myanmar on Rohingya trapped at border", Reuters, 19 February 2018. For more on the Rohingya crisis, see Crisis Group Statement, "The Rakhine State Danger to Myanmar's Transition", 8 September 2017.

${ }^{73}$ See Crisis Group Asia Report $\mathrm{N}^{\circ} \mathbf{2 9 2}$, Myanmar's Rohingya Crisis Enters a Dangerous New Phase, 7 December 2017.

${ }^{74}$ The tenor of long-running discussions between the two countries on the subject suggests that this effort is unrealistic, as do Myanmar's deliberately rigid standards and the continuing crackdown on and isolation of Rohingya communities. "Bangladesh agrees with Myanmar to complete Rohingya return in two years", Reuters, 16 January 2018; "Number of refugees from Myanmar in Bangladesh up to 480,000: Agencies”, Reuters, 25 September 2017; “'Textbook example of ethnic cleansing': 370,00o Rohingyas flood Bangladesh as crisis worsens”, The Washington Post, 12 September 2017. ${ }^{75}$ Crisis Group Report, Myanmar's Rohingya Crisis Enters a Dangerous New Phase, op. cit.

${ }^{76}$ Crisis Group interview, Munir Ahmed, press secretary to Allama Shah Ahmed Shafi, amir, Hefazate-Islam, Chittagong, May 2017. “Annual threat assessment”, Counter Terrorist Trends and Assessments, vol. 9, no. 1 (January 2017). For background on the Rohingya Solidarity Organisation and its
} 
Certainly, too, regional and transnational jihadist networks have shown interest in exploiting the Rohingyas' plight. An April 2016 issue of Dabiq, ISIS's online magazine, included a Bangladeshi ISIS commander sounding a rallying cry to fight for Rohingya rights. Al-Qaeda had included Myanmar on a 2014 list of key targets, and in December 2016 its Bengali media output included a video call to arms to avenge the persecution of Arakan Muslims. In a mid-September 2017 article in the Pakistanbased Jaish-e-Mohammed's main publication, Masood Azhar, its leader, wrote: “All Muslims of the world must unite for this cause. We have to do something and do it urgently. Myanmar's soil is earnestly waiting for the thumping sound of the footsteps of the conquerors". ${ }^{77}$ Akayed Ullah, the Bangladeshi immigrant who detonated a pipe bomb in a New York subway corridor on 11 December 2017, had visited the Rohingya camps three months earlier. ${ }^{78}$ That said, jihadists have long drawn attention to the suffering of Muslims around the world - including, for example, that of the Palestinians - to inspire attacks yet frequently this tactic does not translate into jihadist inroads into the conflicts in question.

Clearly, Bangladeshi authorities must remain alert to such dangers. Overall, though, their response to the Rohingya crisis should involve less counter-terrorism than humanitarian provision for a traumatised refugee population. They should concentrate as well on preventing and containing friction between Rohingyas and host communities.

ties to Bangladeshi militancy, see Crisis Group Asia Reports $\mathrm{N}^{\circ} 283$, Myanmar: A New Muslim Insurgency in Rakhine State, 15 December 2016; and The Threat from Jamaat-ul Mujahideen, op. cit. 77 “Myanmar's Buddhist leader is a coward, unlike bin Laden", Daily Times, 12 September 2017; "Militant outfits look to cash in on Rohingya crisis", Dhaka Tribune, 13 September 2017.

78 "Akayed visited Kutupalong Rohingya camp in October", Dhaka Tribune, 14 December 2017; “A mysterious act of mercy by subway bombing suspect”, The New York Times, 18 December 2017. 


\section{The State's Response}

\section{A. Blunt Force}

Since the 2016 Dhaka attack, law enforcement agencies have raided numerous jihadist hideouts in different parts of the capital, neighbouring Narayanganj and Gazipur, Chittagong, as well as in the north. Yet many counter-terrorism operations seem focused on killing those suspected of involvement with jihadist networks, rather than disrupting or dismantling those networks and countering their influence. ${ }^{79}$ Some of these killings reportedly have been staged as "fake encounters" or gun battles between militants and police in which militants are killed. ${ }^{80}$

Odhikar, a Bangladeshi human rights organisation, estimates that there have been as many as 2,000 such killings since 2001 by the Rapid Action Battalion and police, with 128 in 2016 and 154 in 2017. This group also says at least 330 people, including alleged militants as well as opposition BNP and JeI members, have disappeared since the Awami League government came to office in 2009. ${ }^{81}$ Many others have been detained for long periods without charge. Among the latter category were two survivors of the 2016 Dhaka attack, Hasnat Karim and Tahmid Hasib. Family members claimed that law enforcement personnel had apprehended them from their homes without warrants after images/videos of supposedly suspicious behaviour during the siege emerged on social media. Hasib was detained for almost a year before being released without charge; Karim remains in custody, charged with involvement in the attack, though officials have provided few details. ${ }^{82}$

Since the 2016 attack, the Dhaka metropolitan police's Counter Terrorism and Transnational Crime Unit, rather than the Rapid Action Battalion, has been given the counter-terrorism lead, a shift in authority that aims, according to officials, to build specialised counter-terrorism expertise in the force. But instead of using intelligence for operations aimed at dismantling jihadist groups, the state's response continues to consist mostly of killing suspected militants, as is evident in recent raids in Comilla, Chittagong, Sylhet, Rajshahi and elsewhere. ${ }^{83}$ A district police official acknowledged that extrajudicial killings were common..$^{84}$

\footnotetext{
${ }^{79}$ For example, a month after the Dhaka attack, police raided an apartment in the densely populated Kalyanpur neighbourhood, claiming that nine militants had been killed in a standoff. Since no police were injured, many in the media speculated that the encounter was staged. Similarly, in August 2016, the police claimed to have killed the alleged mastermind of the 2016 Dhaka attack, Tamim Chowdhury, and two accomplices in a gun battle. But there were allegations that Chowdhury had been in police custody for at least two weeks before the supposed encounter. "9 militants killed in Dhaka hideout", The Daily Star, 27 July 2016; "Extremism suspect killed in Lalbagh police raid”, New Age, 11 September 2016.

80 "Bangladesh: End disappearance and secret detentions", Human Rights Watch, 6 July 2017.

${ }^{81}$ See the following Odhikar publications: "Crossfire/gunfight from 2001-2007"; "Bangladesh: annual human rights report 2016" (undated); "Enforced disappearance 2009-2017 February” (March 2017); and "Bangladesh: annual human rights report 2017" (January 2018), p. 30.

${ }^{82}$ David Bergman, "Bangladesh's secret detentions: The case of the two Dhaka attack hostages", The Wire, 12 August 2016.

83 “New JMB Rajshahi military chief killed in gunfight”, Dhaka Tribune, 3 March 2017.

${ }^{84}$ Crisis Group interview, Chandpur, June 2017.
} 
Many government and law enforcement officials believe the criminal justice system incapable of dealing effectively with terrorism cases, as delays and prolonged trials often end without convictions while militants recruit and proselytise in prisons. A former Rapid Action Battalion official claimed that jailed militants established protection rackets for petty criminals, whom they eventually recruit. ${ }^{85} \mathrm{~A}$ prison official suggested that prisons employ Islamic scholars: "I find myself at sea trying to argue religion with [detained] militants, who know a lot more about Islam than I do. How am I meant to prevent radicalisation here?"86

Circumvention of the criminal justice system is clearly the wrong response, however. It undermines the state's legitimacy, sows fear and mistrust between authorities and communities, and risks provoking a violent backlash. The culture of impunity it breeds also erodes professionalism in the security forces and in some cases appears to have encouraged other forms of criminality. Some members are involved in contract killings and kidnappings for ransom; in 2014, a spate of murders in Narayanganj involved top Rapid Action Battalion officials including a former army lieutenant colonel. ${ }^{87}$

Human rights activists argue that the culture of impunity around enforced disappearances and unlawful detention has a lasting impact on victims and their families and undercuts the government's internal security objectives ${ }^{88}$ Extrajudicial killings feed jihadist propaganda about injustice; Ansar has shared images of those killed during the 2013 Hefazat protests through its Telegram channel to entice new recruits. ${ }^{89}$

Some law enforcement officials also express concern that killing rather than apprehending militants wastes opportunities to obtain vital intelligence. A security official contended that a killing in 2015 in which he was involved might have cost law enforcement agencies an opportunity to uncover planning for and disrupt the 2016 Dhaka attack..$^{\circ}$ Other security officials said the killing of captured militants prevented investigation of suspected cells, including in regions close to Bangladesh's border with India..$^{91}$ Inadequate investigations and questioning of arrested militants may lead to similarly squandered opportunities. A prominent human rights activist argued, for example, that more thorough investigations of arrested militants' involvement in earlier attacks on foreigners could have yielded intelligence about impending attacks, including that same Dhaka attack. ${ }^{92}$

\footnotetext{
${ }^{85}$ Crisis Group interview, Dhaka, June 2017.

${ }^{86}$ Crisis Group interview, district jail official, Chandpur, June 2017.

${ }^{87}$ In April 2014, seven people, including a Naranyanganj city councillor and a lawyer, were abducted and killed. At least 27 RAB officials, including three top officials seconded from the army, were found responsible for the contract killing commissioned by a rival politician of the ruling party. "7-murder: Nur Hossain, RAB commander Tareque, 24 others get death", The Daily Star, 16 January 2017.

${ }^{88}$ Crisis Group interviews, Dhaka, August 2017.

${ }^{89}$ Crisis Group review of Ansar posts on social media app Telegram, September 2017.

${ }^{90}$ Crisis Group interviews, security officials, Dhaka, June-August 2017.

${ }^{91}$ Ibid.

${ }^{92}$ Crisis Group interviews, counter-terrorism officials, Chittagong, June 2017; Nur Khan Liton, human rights activist, Dhaka, August 2017.
} 


\section{B. Following the Money}

Jihadist groups raise funds from multiple sources. Militants' families apparently contribute considerable sums for individual attacks, to hide and train operatives, and to acquire weapons. Zakat, obligatory Islamic alms for the poor, was a major funding source for the previous generation of jihadists and is still tapped by such groups. ${ }^{93}$

Bangladesh's long, porous borders with India and Myanmar pose particular challenges to countering the flow of illicit funds, some of which may end up bankrolling jihadist operations. Indeed, Bangladesh is "a trans-shipment point for drugs produced in both the 'golden triangle' of Southeast Asia and 'golden crescent' of Central Asia". ${ }^{94}$ According to a former senior security official, jihadist outfits also depend on forged Indian currency from Pakistan..$^{95}$ Individuals as well as organisations from Saudi Arabia and Kuwait in particular fund madrasas and mosques across Bangladesh, with some of the money apparently finding its way to jihadist groups. ${ }^{96}$

Particularly vexing is the jihadist use of hundi, an informal domestic and international money transfer mechanism. For the most part, this mechanism is benign: an estimated six million Bangladeshis working in the Middle East and South East Asia send home about $\$ 12-15$ billion annually, about half of it through hundi. ${ }^{97}$ But JMB has long run its own hundi operations that provide both profits and a secure method of moving funds.$^{98}$ Moving small sums over time is a simple way of evading detection. The central bank, Bangladesh Bank, has had marginal success in screening these transfers. More promising are its attempts to make more attractive the use of regular banking channels for remittances.

The government has taken steps to counter money laundering and terrorist financing. The 2009 Anti-Terrorism Act empowered Bangladesh Bank to freeze accounts and take other actions to curb criminal activity. The Money Laundering Prevention Act of 2012 and 2013 amendments to the Anti-Terrorism Act lengthened the list of money laundering offenses and expanded the categories of reporting entities, while widening the scope of legal sanctions. The 2012 Mutual Legal Assistance Act aimed to strengthen international cooperation efforts. And Bangladesh became a member of the Asia Pacific Group on money laundering in July 2013.

These efforts have met with international approval. In February 2014, the international Financial Action Task Force removed Bangladesh from its "grey list" which includes "jurisdictions with strategic AML [Anti-Money Laundering]/CFT [Combatting the Financing of Terrorism] deficiencies that have not made sufficient progress

\footnotetext{
${ }^{93}$ Crisis Group interviews, serving and retired security officials, Dhaka, June 2017; "A year after Gulshan attack, police are still looking for five fugitives”, Dhaka Tribune, 1 July 2017; and Crisis Group Report, The Threat from Jamaat-ul Mujahideen, op. cit.

942014 International Narcotics Control Strategy Report, U.S. Bureau of International Narcotics and Law Enforcement Affairs, U.S. State Department, 2014.

95 Crisis Group interview, Dhaka, June 2017.

${ }^{96}$ Crisis Group Report, The Threat from Jamaat-ul Mujahideen, op. cit.; "Militant funding: 17 foreign NGOs under intel surveillance", Dhaka Tribune, 19 July 2017. See also "Saudi Arabia giving \$20 million for Bangladesh mosques”, BDNews24.com, 26 September 2017.

97 “Overseas employment remittances from 1976 to 2017", Bureau of Manpower, Employment and Training, Ministry of Expatriates' Welfare and Overseas Employment, Government of Bangladesh: http://www.bmet.gov.bd/BMET/stattisticalDataAction.

${ }^{98}$ Crisis Group Report, The Threat from Jamaat-ul Mujahideen, op. cit.
} 
in addressing the deficiencies", ${ }^{99}$ and an October 2016 Asia Pacific Group assessment noted significant improvement in compliance with international anti-money laundering and counter-terrorism financing standards. ${ }^{100}$ It also found that the Bangladesh Bank's Financial Intelligence Unit effectively disseminated information to law enforcement and other agencies. The 2017 Basel anti-money laundering index, published by the Switzerland-based Babel Institute on Governance, ranked Bangladesh second in South Asia behind India. ${ }^{101}$

Bangladeshi authorities now need to get better at investigating and prosecuting complex financial crimes. The state has won very few money laundering and terrorist financing convictions, though hundreds of cases are pending. ${ }^{102}$ Law enforcement agencies lack the capacity to collate and understand financial intelligence, including that gathered by the Bangladesh Financial Intelligence Unit, and at making use of that intelligence in their investigations. ${ }^{103}$

\section{Politicising Counter-terrorism}

Rather than building political consensus on the threat posed by jihadist groups and how to tackle it, Prime Minister Hasina's government has more often exploited the militants' attacks to discredit the opposition. Awami League leaders accuse the BNP of assisting militants when it was in office from 2001-2006; some of them go so far as to accuse it of involvement in high-profile jihadist attacks since 2015 .

Condemning the 2016 Dhaka attack, Hasina blamed those who "have resorted to terrorism after failing to win the hearts of people democratically", a thinly veiled reference to the BNP and its JeI allies. ${ }^{104}$ Even before the investigation into the August 2015 murder of Italian national Cesare Tavella started, Hasina pointed to the BNP and JeI; three weeks later the home minister, without evidence, named a BNP leader as the murder's mastermind. ${ }^{105}$ In October 2016, a year after police had charged seven people, including a mid-ranking BNP member, for that murder, the Rapid Action Battalion held JMB responsible. Even now that internal government documents attribute the killing to the "neo-Jamaat-ul Mujahideen" and nothing suggests the BNP member who has been charged has ties to that group, his trial continues. ${ }^{106}$

Notwithstanding the BNP's mixed record of combatting militancy while in office in the 2000s, the governments' accusations of BNP support for such groups today

\footnotetext{
${ }^{99}$ FATF website, www.fatf-gafi.org.

100 "Anti-money laundering and counter-terrorist financing measures: Bangladesh”, Mutual Evaluation Report, Asia/Pacific Group on Money Laundering, October 2016; Basel AML Index Report, Basel Institute of Governance, 16 August 2017.

${ }^{101}$ Ibid.

102 “Anti-money laundering and counter-terrorist financing measures: Bangladesh”, op. cit.

103 Ibid.

104 "PM blames it on local, int'l quarters", The Daily Star, 3 July 2016.

${ }^{105}$ Hasina was quoted as saying that the BNP and Jamaat have "definitely abetted these murders in an attempt to overshadow Bangladesh's achievements". "Hasina accused 'BNP-Jamaat' of killing foreigners in Bangladesh”, BDNews24.com, 4 October 2015.

${ }^{106}$ Internal government documents provided to Crisis Group. "Tavella shot dead 'by neo JMB”, The Daily Star, 22 October 2016; "Bangladesh minister accuses BNP man of Italian's murder", Economic Times, 28 October 2015; "Bangladesh PM Hasina smells link of BNP-Jamaat”, The Daily Star, 5 October 2015.
} 
have little credibility and serve mainly as a way for the ruling party to tarnish its principal political rival. Similar accusations against JeI are equally politicised, as evidenced by the measures taken to force the party from politics and its base almost entirely underground. With the JeI weakened and many senior leaders executed following the war crimes trials, there is a risk that some supporters throw in their lot with harder-line groups, as avenues to pursue goals peacefully close.

The party's student wing, Shibir, was once a key source of recruits for JMB, whose founder Shaikh Abdur Rahman was a Shibir member. One senior counter-terrorism official claimed that several former leaders of Shibir, which has a long history of violence, have joined jihadist organisations in recent years. It is, however, difficult to assess government and even nominally independent analysts' claims of links between JeI and jihadists, particularly given the repression the JeI has suffered over the past years and the partisan agendas of many domestic observers. ${ }^{107}$ Leaders of JeI and its student wing deny allegations that party members have turned to jihadism, scorning those charges as a government conspiracy to discredit the party. ${ }^{108}$ A Shibir leader said: "Judicial commissions had been formed in the past to find our links to militancy and found nothing" ${ }^{109}$ Yet suppressing the largest Islamist party could, by pushing its supporters underground, work to jihadists' advantage.

${ }^{107}$ Crisis Group interviews, CTTC official, Dhaka, June 2017; and security analyst, January 2018. See also “New JMB's Shibir connection”, Dhaka Tribune, 17 August 2017.

${ }^{108}$ Crisis Group interviews, Jamaat-e-Islami and Islami Chhatra Shibir central leadership, Dhaka and Magura, June-August 2017.

${ }^{109}$ Crisis Group interview, Islami Chhatra Shibir finance secretary, Magura, April 2017. 


\section{Improving the Government's Response}

\section{A. Reforming the Criminal Justice System}

Law enforcement agencies in Bangladesh rely on brute force in part because the criminal justice system is enfeebled, with poor investigative capacity, weak prosecutors and a paralysing backlog of court cases. This is particularly the case in rural communities where significant jihadist recruitment takes place and police are poorly paid, prone to corruption and lacking in basic training. Together, these factors have allowed scores, possibly hundreds, of detained militants to escape punishment. ${ }^{110}$

By resorting to extrajudicial methods to overcome these problems, the state plays into jihadists' hands, as such tactics harden popular perceptions of politicisation and score settling. A prominent ex-military security analyst said: "If extrajudicial killings continue, there is a possibility we will get more and more extremists. They can now say, "we told you there is no rule of law and this is the evidence". ${ }^{111}$ Killing alleged jihadists is doubly injurious: it validates this view while impeding intelligence gathering.

It seems some political leaders would rather continue to use the flawed justice system against rivals than reform it. But hampering the ability of the police and courts to tackle the threat presented by jihadist groups will almost certainly erode the government's own position. To implement a more effective counter-terrorism strategy, it will need to address the causes of its deteriorating criminal justice system, notably obsolete investigation methods and resources as well as the failure to professionalise police and prosecution agencies. ${ }^{112}$

\section{B. Political Reconciliation and Democratic Debate}

Of equal importance, the government ought to redress the acute politicisation that has created space for the re-emergence of jihadist movements and hindered efforts to tame the threat they pose. That task will require a reorientation of present exclusionary policies. The Awami League, which claims to be the sole political custodian of the country's constitutionally mandated secularism, has painted the opposition BNP as having been soft on militancy when in government and now, in opposition, reliant on groups such as JeI, which - the government argues - are friendly to or even conveyor belts toward jihadism.

That welter of accusations is dubious on several counts. Certainly, the BNP's track record in office was at best inauspicious; its rule between 2001-2006 saw an increase in militant activity (see Section II above). But the Awami League government's marginalisation of the BNP and JeI ahead of the December general election is politically motivated. Khaleda Zia's 8 February conviction and five-year sentence for corruption, whose timing suits the Awami League's electoral planning, could

\footnotetext{
110 “148 'militants' out on bail create fresh threat”, Protom Alo, 13 June 2017.

${ }^{111}$ Crisis Group interview, Major General (retired) Moniruzzaman, Dhaka, August 2017.

${ }^{112}$ For detailed analysis and recommendations, see Crisis Group Report, Political Conflict, Extremism and Criminal Justice in Bangladesh, op. cit.
} 
prohibit her from contesting the polls and widen divisions. ${ }^{113}$ At the same time, the government is making its own concessions to Islamists, notably Hefazat, whose views it opposes the principle of a pluralist, secular democracy; allowing women in the workplace; or appointing Hindus to key government posts - are arguably harderline than those of JeI. ${ }^{114}$

In January 2017, responding to criticism from Hefazat, the government agreed to remove contributions by non-Muslim and secular authors in public school textbooks. In April, the education ministry agreed to recognise qaumi madrasa higher education degrees (known as dawra-e-Hadith) as equivalent to a master's degree, despite the absence of regulation or enforcement of education standards in the madrasas. This decision effectively opened to madrasa graduates employment opportunities that are closed to others with the same limited formal schooling. The following month, Prime Minister Hasina supported Hefazat's demand to remove a statue of Lady Justice, which the group deemed un-Islamic, in front of the Supreme Court. ${ }^{115}$ These concessions are effectively giving greater currency to the Hefazat's hardline exclusionary agenda.

The government's targeting of BNP and JeI risks doing jihadist groups a service. Not only does it divert police resources from disrupting jihadist recruitment and planning. But, in addition, by depriving JeI of legitimate platforms for dissent and exposing it to a harsh crackdown, the government might force some JeI activists to follow exactly the path it accuses them of taking already - the path toward finding common cause with militants. The BNP joint secretary general warned: "Only a return to a multiparty democratic space can ensure solutions to rising militancy". ${ }^{116}$ Some in the Awami League harbour similar misgivings, but the party's top decision-makers fear losing to the BNP in a credible election, which would be the basis of any meaningful engagement between the two parties, and thus prefer the current stalemate. ${ }^{117}$

While the Supreme Court decision on the JeI's participation in elections appears for now difficult to reverse, the government's crackdowns on the party and the BNP are counterproductive. Instead, the Awami League would be better served by forging consensus with the BNP on how to tackle the threat. Zia's conviction has made such a dialogue even more elusive. Her party, whose activists have already resorted to street

\footnotetext{
${ }^{113}$ The chief election commissioner said Zia cannot contest the next general election unless she persuades the Supreme Court to overturn her conviction or lessen her sentence. "Khaleda can't run polls in present context: CEC", The Daily Star, 19 February 2018.

${ }^{114}$ Hefazat leaders deny any direct political ambitions, though they do call themselves the "kingmaker" in Bangladeshi politics. Crisis Group interview, Munir Ahmed, press secretary to Allama Shah Ahmed Shafi, amir, Hefazat-e-Islam, Chittagong, May 2017.

${ }^{115}$ Secular activists and sections of the media denounced these measures as kowtowing to Islamist hardliners. See "Removal of statue is capitulation to communalism", The New Age, 28 May 2017; "Lady Justice statue in Bangladesh is removed after Islamist objections", The Guardian, 26 May 2017; "To secular Bangladeshis, textbook changes are a harbinger", The New York Times, 22 January 2017. Even an Awami League leader went so far as to say that the government was trying to buy Hefazat's support. Crisis Group interview, Awami League advisory council member, Dhaka, May 2017.

${ }^{116}$ Crisis Group interview, Ruhul Kabir Rizvi, Bangladesh Nationalist Party joint secretary general, Dhaka, August 2017.

${ }^{117}$ Crisis Group interviews, Awami League members, Dhaka, August 2017.
} 
agitation - which could turn violent - has said it will not field candidates in December if she remains imprisoned; another virtually uncontested election would further erode government legitimacy and risk violent BNP-Awami League clashes as in 2014. ${ }^{118}$

The Supreme Court could reduce Zia's sentence on appeal to less than two years, thus removing any prohibition on her own electoral candidacy. Whatever the outcome of the appeal, in the interest of social peace, the Awami League should withdraw politically motivated corruption and criminal charges against Zia and other senior BNP officeholders and stop the repression of their supporters. The BNP should urge its cadres to exercise restraint, rather than turning to violence, and craft a compromise with the government. The alternative is continued confrontation and zero-sum politics that will increase the risks of another deeply contested election, with jihadists potentially taking advantage of any ensuing crisis or violence.

\section{Curbing Recruitment: Engaging Bangladesh's Youth}

Police officers, lawyers, and others who have interacted with jihadists contend that large numbers of militants are drawn to jihadist ideas online prior to joining violent groups. ${ }^{119}$ That said, there is little credible research on what drives recruitment or on the profile of those recruited, beyond approximate age group (15-35) and broad geographic location (with a heavy concentration in northern regions). Indeed, recruits show enormous diversity: from madrasa students to upper middle-class youth at private universities. A senior counter-terrorism official admitted: "We are struggling to disrupt recruitment". ${ }^{120}$

The government has adopted some strategies beyond law enforcement to counter the appeal of jihadism. Its approach includes public awareness campaigns and training muezzins (mosque preachers) to give anti-militancy sermons at Friday prayers. ${ }^{121}$ But the effectiveness of such measures remains unproven and, in any case, they are inconsistently implemented.

Little has been done to regulate the qaumi madrasas, which teach around 1.4 million students in rural and other economically deprived areas, and which continue to supply a potential, if limited, pool of recruits and sympathisers. ${ }^{122}$ Aliya madrasas are largely state-funded and registered under the government-mandated Bangladesh Madrasa Education Board, which also designs curricula, holds exams and contracts textbook production. In contrast, the qaumi sector evades government supervision, even as security officials suggest tighter monitoring. The Awami League government's decision to formally recognise a qaumi madrasa degree as equivalent to a master's

\footnotetext{
118 "BNP rules out going to election with Khaleda in jail”, BDNews24.com, 18 February 2018.

${ }^{119}$ Crisis Group interviews, Dhaka, June-August 2017.

${ }^{120}$ Crisis Group interview, Dhaka, April 2017.

${ }^{121}$ The government has inter-ministerial committees instructing various ministries, including religious affairs, culture, information, education and law, to conduct counter-extremism campaigns. Ministry records suggest that Friday sermons against militancy have been delivered at over 300,000 mosques. Prominent international clerics have been invited to speak against radicalisation, and documentaries and television advertisements with the same message have been aired. Crisis Group interviews, government officials, Dhaka, August 2017.

122 "Modernisation of madrasa education in Bangladesh: a strategy paper", Bangladesh Enterprise Institute, June 2011.
} 
degree only makes these seminaries more attractive. ${ }^{123}$ To be sure, the vast majority of madrasa students do not turn to jihadism, but the lack of government regulation allows for the promotion of sectarian intolerance and, in some cases, even incitement to violence. Until there is greater state oversight over the madrasa curriculum, the government should rescind its master's degree decision.

The challenge goes well beyond the madrasa sector, though. Private university campuses like North South's have also seen students drawn to jihadism, whereupon they have perpetrated some of the most lethal attacks at home and/or travelled to join ISIS in Iraq and Syria. ${ }^{124}$ Yet security agencies appear far more focused on countering opposition to the government than disrupting jihadism recruitment on campuses. While political polarisation deepens and the partisan crackdowns on the Awami League's rivals continue, that is likely to remain the case.

${ }^{123}$ Crisis Group interview, Awami League advisory council member, Dhaka, June 2017.

124 “Latest Bangladeshi IS fighter killed in Iraq is Taz Rahman”, Dhaka Tribune, 12 May 2017; Saroj Kumar Rath, “Wolf-Pack terrorism: Inspired by ISIS, made in Bangladesh”, YaleGlobal Online, 5 July 2016. 


\section{Conclusion}

Although there was no major attack in 2017, the potential for further jihadist violence in Bangladesh remains. The resurgence of jihadist groups over the past few years has been facilitated if not accelerated by years of political deadlock. While there is no direct line between toxic politics and the rise of jihadist violence, a bitterly divided polity, between those espousing secularism and those emphasising Bangladesh's Muslim identity, and a brutal and highly partisan policing and justice system, nonetheless has opened space for jihadist groups. The politicised trials of senior JeI leaders contributed to the environment in which Ansar emerged. The BNP's alliance with the JeI, whose activists, along with BNP cadres, have been responsible for much of the worst political violence since 2013, raises understandable concerns. Yet that violence was provoked by the attempt to drive JeI underground, itself the byproduct of a zero-sum game between the two largest parties.

Ending the deadlock is even more urgent today as Bangladesh confronts a new generation of potentially more dangerous jihadists with apparent links to transnational terror groups such as ISIS. Instead, Sheikh Hasina's government has made no serious attempt to reconcile with the mainstream opposition, opting instead to waste police resources on repression of opponents. This choice has undermined both democracy and security, with countrywide violence bringing the country to a standstill for months at a time. Given the jihadist revival since then, another breakdown of law and order would almost certainly play into the hands of groups like Ansar and JMB. If the government does not change course, such forces may experience another resurgence. 


\section{Appendix A: Map of Bangladesh}

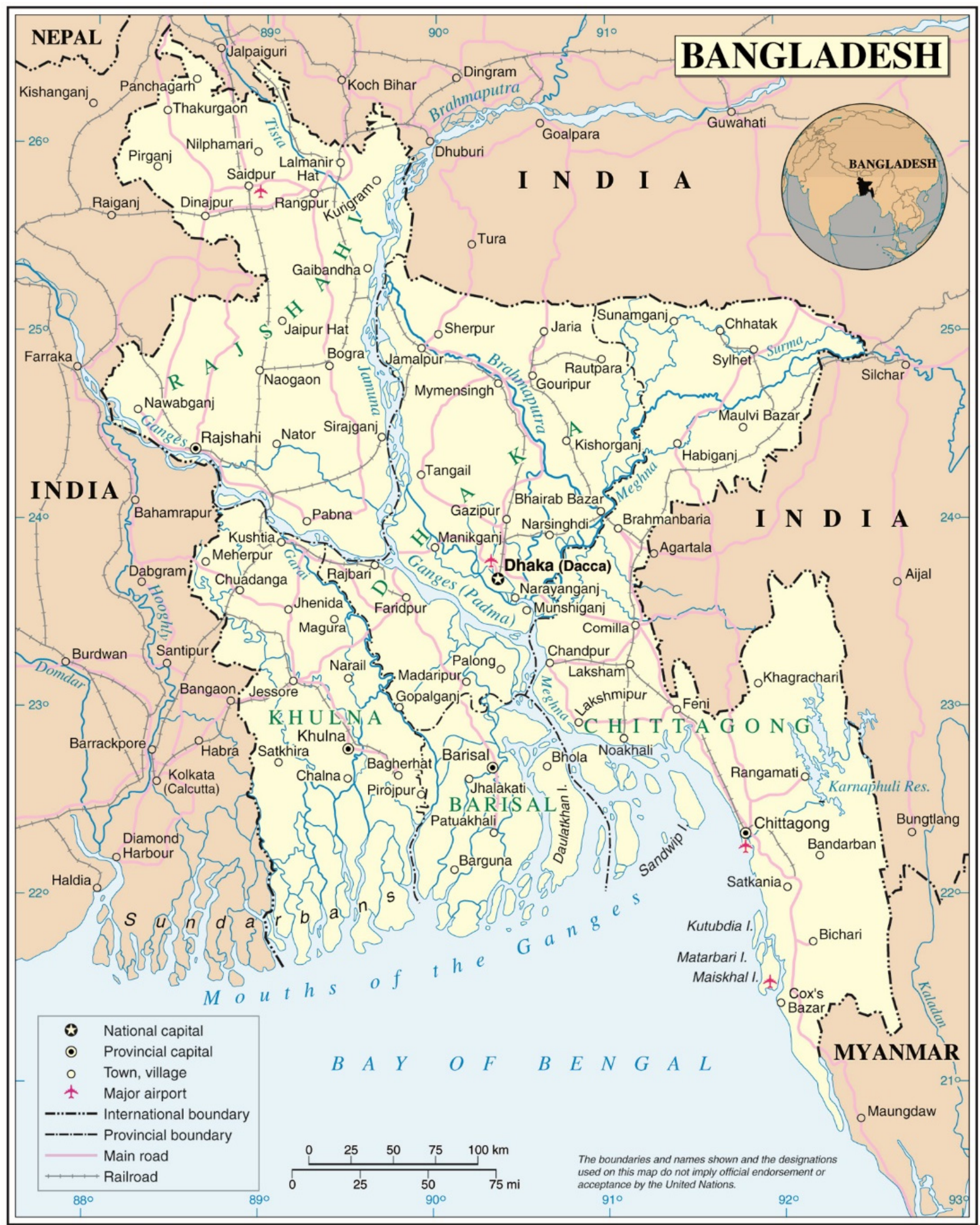




\section{Appendix B: About the International Crisis Group}

The International Crisis Group (Crisis Group) is an independent, non-profit, non-governmental organisation, with some 120 staff members on five continents, working through field-based analysis and high-level advocacy to prevent and resolve deadly conflict.

Crisis Group's approach is grounded in field research. Teams of political analysts are located within or close by countries or regions at risk of outbreak, escalation or recurrence of violent conflict. Based on information and assessments from the field, it produces analytical reports containing practical recommendations targeted at key international, regional and national decision-takers. Crisis Group also publishes CrisisWatch, a monthly early warning bulletin, providing a succinct regular update on the state of play in up to 70 situations of conflict or potential conflict around the world

Crisis Group's reports are distributed widely by email and made available simultaneously on its website, www.crisisgroup.org. Crisis Group works closely with governments and those who influence them, including the media, to highlight its crisis analyses and to generate support for its policy prescriptions.

The Crisis Group Board of Trustees - which includes prominent figures from the fields of politics, diplomacy, business and the media - is directly involved in helping to bring the reports and recommendations to the attention of senior policymakers around the world. Crisis Group is chaired by former UN Deputy Secretary-General and Administrator of the United Nations Development Programme (UNDP), Lord Mark Malloch-Brown. Its Vice Chair is Ayo Obe, a Legal Practitioner, Columnist and TV Presenter in Nigeria.

Crisis Group's President \& CEO, Robert Malley, took up the post on 1 January 2018. Malley was formerly Crisis Group's Middle East and North Africa Program Director and most recently was a Special Assistant to former U.S. President Barack Obama as well as Senior Adviser to the President for the Counter-ISIL Campaign, and White House Coordinator for the Middle East, North Africa and the Gulf region. Previously, he served as President Bill Clinton's Special Assistant for Israeli-Palestinian Affairs.

Crisis Group's international headquarters is in Brussels, and the organisation has offices in ten other locations: Bishkek, Bogota, Dakar, Kabul, Islamabad, Istanbul, Nairobi, London, New York, and Washington, DC. It has presences in the following locations: Abuja, Algiers, Bangkok, Beirut, Caracas, Gaza City, Guatemala City, Hong Kong, Jerusalem, Johannesburg, Juba, Mexico City, New Delhi, Rabat, Sanaa, Tblisi, Toronto, Tripoli, Tunis, and Yangon.

Crisis Group receives financial support from a wide range of governments, foundations, and private sources. Currently Crisis Group holds relationships with the following governmental departments and agencies: Australian Department of Foreign Affairs and Trade, Austrian Development Agency, Canadian Department of Foreign Affairs, Trade and Development, Danish Ministry of Foreign Affairs, Dutch Ministry of Foreign Affairs, European Union Instrument contributing to Stability and Peace (IcSP), European Commission, Directorate General for Neighbourhood Enlargement Negotiations, Finnish Ministry for Foreign Affairs, French Development Agency, French Ministry of Foreign Affairs, German Federal Foreign Office, Global Affairs Canada, Irish Aid, Principality of Liechtenstein, Luxembourg Ministry of Foreign Affairs, New Zealand Ministry of Foreign Affairs and Trade, Norwegian Ministry of Foreign Affairs, Swedish Ministry of Foreign Affairs, and the Swiss Federal Department of Foreign Affairs.

Crisis Group also holds relationships with the following foundations: Carnegie Corporation of New York, Heinrich Böll Stiftung, Henry Luce Foundation, Humanity United, John D. and Catherine T. MacArthur Foundation, Oak Foundation, Omidyar Network Fund, Open Society Foundations, Ploughshares Fund, Robert Bosch Stiftung, and Wellspring Philanthropic Fund.

\section{February 2018}




\section{Appendix C: Reports and Briefings on Asia since 2015}

\section{Special Reports}

Exploiting Disorder: al-Qaeda and the Islamic State, Special Report N¹, 14 March 2016 (also available in Arabic and French).

Seizing the Moment: From Early Warning to Early Action, Special Report N², 22 June 2016.

Counter-terrorism Pitfalls: What the U.S. Fight against ISIS and al-Qaeda Should Avoid, Special Report N³, 22 March 2017.

\section{North East Asia}

Stirring up the South China Sea (III): A Fleeting Opportunity for Calm, Asia Report N ${ }^{\circ} 267$, 7 May 2015 (also available in Chinese).

North Korea: Beyond the Six-Party Talks, Asia Report N²69, 16 June 2015.

Stirring up the South China Sea (IV): Oil in Troubled Waters, Asia Report N²75, 26 January 2016 (also available in Chinese).

East China Sea: Preventing Clashes from Becoming Crises, Asia Report $N^{\circ} 280,30$ June 2016.

China's Foreign Policy Experiment in South Sudan, Asia Report N²88, 10 July 2017 (also available in Chinese).

The Korean Peninsula Crisis (I): In the Line of Fire and Fury, Asia Report №293, 23 January 2018.

The Korean Peninsula Crisis (II): From Fire and Fury to Freeze-for-Freeze, Asia Report N²94, 23 January 2018.

\section{South Asia}

Mapping Bangladesh's Political Crisis, Asia Report $\mathrm{N}^{\circ} 264,9$ February 2015.

Women, Violence and Conflict in Pakistan, Asia Report N²65, 8 April 2015.

The Future of the Afghan Local Police, Asia Report N²68, 4 June 2015.

Revisiting Counter-terrorism Strategies in Pakistan: Opportunities and Pitfalls, Asia Report $\mathrm{N}^{\circ} 271,22$ July 2015.

Sri Lanka Between Elections, Asia Report $\mathrm{N}^{\circ} 272,12$ August 2015.

Winning the War on Polio in Pakistan, Asia Report $\mathrm{N}^{\circ} 273,23$ October 2015.

Nepal's Divisive New Constitution: An Existential Crisis, Asia Report N²76, 4 April 2016.

Political Conflict, Extremism and Criminal Justice in Bangladesh, Asia Report N²77, 11 April 2016.

Sri Lanka: Jumpstarting the Reform Process, Asia Report N²78, 18 May 2016.

Pakistan's Jihadist Heartland: Southern Punjab, Asia Report N²79, 30 May 2016.

Pakistan: Stoking the Fire in Karachi, Asia Report $N^{\circ} 284,15$ February 2017.
Afghanistan: The Future of the National Unity Government, Asia Report N²85, 10 April 2017.

Sri Lanka's Transition to Nowhere, Asia Report N²86, 16 May 2017.

Sri Lanka's Conflict-Affected Women: Dealing with the Legacy of War, Asia Report N²89, 28 July 2017.

\section{South East Asia}

Myanmar's Electoral Landscape, Asia Report $\mathrm{N}^{\circ}$ 266, 28 April 2015 (also available in Burmese).

Southern Thailand: Dialogue in Doubt, Asia Report $N^{\circ} 270,8$ July 2015.

Myanmar's Peace Process: A Nationwide Ceasefire Remains Elusive, Asia Briefing $N^{\circ} 146,16$ September 2015 (also available in Burmese).

The Myanmar Elections: Results and Implications, Asia Briefing N¹47, 9 December 2015 (also available in Burmese).

Thailand's Lengthening Roadmap to Elections, Asia Report N²74, 10 December 2015.

The Philippines: Renewing Prospects for Peace in Mindanao, Asia Report N²81, 6 July 2016.

Myanmar's New Government: Finding Its Feet?, Asia Report N²82, 29 July 2016 (also available in Burmese).

Southern Thailand's Peace Dialogue: No Traction, Asia Briefing N¹48, 21 September 2016.

Myanmar's Peace Process: Getting to a Political Dialogue, Asia Briefing N¹49, 19 October 2016 (also available in Burmese).

Myanmar: A New Muslim Insurgency in Rakhine State, Asia Report N²83, 15 December 2016 (also available in Burmese).

Building Critical Mass for Peace in Myanmar, Asia Report N²87, 29 June 2017 (also available in Burmese).

Buddhism and State Power in Myanmar, Asia Report N²90, 5 September 2017 (also available in Burmese).

Jihadism in Southern Thailand: A Phantom Menace, Asia Report N²91, 8 November 2017 (also available in Thai and Malay).

Myanmar's Rohingya Crisis Enters a Dangerous New Phase, Asia Report N²92, 7 December 2017 (also available in Burmese). 


\section{Appendix D: International Crisis Group Board of Trustees}

\section{CO-CHAIR}

Lord (Mark) Malloch-Brown

Former UN Deputy Secretary-General

and Administrator of the United

Nations Development Programme

(UNDP)

\section{PRESIDENT \& CEO}

\section{Robert Malley}

Former White House Coordinator

for the Middle East, North Africa and the Gulf region

\section{VICE-CHAIR}

Ayo Obe

Chair of the Board of the Gorée Institute (Senegal); Legal Practitioner (Nigeria)

\section{OTHER TRUSTEES}

\section{Fola Adeola}

Founder and Chairman, FATE Foundation

\section{Celso Amorim}

Former Minister of External Relations of Brazil; Former Defence Minister

\section{Hushang Ansary}

Chairman, Parman Capital Group LLC; Former Iranian Ambassador to the U.S. and Minister of Finance and

Economic Affairs

\section{Nahum Barnea}

Political Columnist, Israel

\section{Kim Beazley}

Former Deputy Prime Minister of Australia and Ambassador to the U.S. Former Defence Minister

\section{Carl Bildt}

Former Prime Minister and Foreign Minister of Sweden

\section{Emma Bonino}

Former Foreign Minister of Italy and European Commissioner for Humanitarian Aid

\section{Cheryl Carolus}

Former South African High

Commissioner to the UK and Secretary General of the African National Congress (ANC)

\section{Maria Livanos Cattau}

Former Secretary General of the International Chamber of Commerce

\section{Wesley Clark}

Former NATO Supreme Allied Commande

\section{Sheila Coronel}

Toni Stabile Professor of Practice in Investigative Journalism; Director,

Toni Stabile Center for Investigative Journalism, Columbia University

\section{Frank Giustra}

President \& CEO, Fiore Financial Corporation

\section{Mo Ibrahim}

Founder and Chair, Mo lbrahim Foundation; Founder, Celtel International

\section{Wolfgang Ischinger}

Chairman, Munich Security

Conference; Former German Deputy

Foreign Minister and Ambassador to the UK and U.S.

\section{Yoriko Kawaguchi}

Former Foreign Minister of Japan;

former Environment Minister

Wadah Khanfar

Co-Founder, Al Sharq Forum; former Director General, Al Jazeera Network

\section{Wim Kok}

Former Prime Minister of the Netherlands

\section{Andrey Kortunov}

Director General of the Russian International Affairs Council

\section{Ivan Krastev}

Chairman of the Centre for Liberal Strategies (Sofia); Founding Board Member of European Council on

Foreign Relations

\section{Ricardo Lagos}

Former President of Chile

Joanne Leedom-Ackerman

Former International Secretary of PEN International; Novelist and journalist, U.S.

\section{Helge Lund}

Former Chief Executive BG Group (UK) and Statoil (Norway)

\section{Shivshankar Menon}

Former Foreign Secretary of India; former National Security Advisor

\section{Naz Modirzadeh}

Director of the Harvard Law School Program on International Law and Armed Conflict

\section{Saad Mohseni}

Chairman and Chief Executive Officer of MOBY Group

\section{Marty Natalegawa}

Former Minister of Foreign Affairs of Indonesia, Permanent Representative to the UN, and Ambassador to the UK

\section{Roza Otunbayeva}

Former President of the Kyrgyz

Republic; Founder of the International Public Foundation "Roza Otunbayeva Initiative"

\section{Thomas R. Pickering}

Former U.S. Under Secretary of State and Ambassador to the UN, Russia India, Israel, Jordan, El Salvador and Nigeria

\section{Olympia Snowe}

Former U.S. Senator and Member of the House of Representatives
Javier Solana

President, ESADE Center for Global Economy and Geopolitics; Distinguished Fellow, The Brookings Institution

\section{Alexander Soros}

Global Board Member, Open Society Foundations

\section{George Soros}

Founder, Open Society Foundations and Chair, Soros Fund Management

\section{Pär Stenbäck}

Former Minister of Foreign Affairs and of Education, Finland; Chairman of the European Cultural Parliament

\section{Jonas Gahr Støre}

Leader of the Labour Party and Labour Party Parliamentary Group; former Foreign Minister of Norway

\section{Lawrence $H$. Summers}

Former Director of the U.S. National Economic Council and Secretary of the U.S. Treasury; President Emeritus of Harvard University

Helle Thorning-Schmidt CEO of Save the Children International; former Prime Minister of Denmark

\section{Wang Jisi}

Member, Foreign Policy Advisory Committee of the Chinese Foreign Ministry; President, Institute of International and Strategic Studies, Peking University 
PRESIDENT'S COUNCIL

A distinguished group of individual and corporate donors providing essential support and expertise to Crisis Group.

$\begin{array}{lll}\text { CORPORATE } & \text { INDIVIDUAL } & \\ \text { BP } & \text { (5) Anonymous } & \text { Stephen Robert } \\ \text { Shearman \& Sterling LLP } & \text { Scott Bessent } & \text { Luděk Sekyra } \\ \text { Statoil (U.K.) Ltd. } & \text { David Brown \& Erika Franke } & \text { Alexander Soros } \\ \text { White \& Case LLP } & \text { Herman De Bode } & \text { lan R. Taylor }\end{array}$

INTERNATIONAL ADVISORY COUNCIL

Individual and corporate supporters who play a key role in Crisis Group's efforts to prevent deadly conflict.

$\begin{array}{ll}\text { CORPORATE } & \text { INDIVIDUAL } \\ \text { Anonymous } & \text { (3) Anonymous } \\ \text { APCO Worldwide Inc. } & \text { Mark Bergman } \\ \text { Atlas Copco AB } & \text { Stanley Bergman \& Edward } \\ \text { Chevron } & \text { Bergman } \\ \text { Edelman UK } & \text { David \& Katherine Bradley } \\ \text { Eni } & \text { Eric Christiansen } \\ \text { HSBC Holdings PIc } & \text { Sam Englebardt } \\ \text { MetLife } & \text { The Edelman Family Foundation } \\ \text { Noble Energy } & \text { Seth \& Jane Ginns } \\ \text { RBC Capital Markets } & \text { Ronald Glickman } \\ \text { Shell } & \text { David Harding } \\ & \text { Geoffrey R. Hoguet \& } \\ & \text { Ana Luisa Ponti } \\ & \text { Geoffrey Hsu } \\ & \text { David Jannetti }\end{array}$

Faisel Khan
Cleopatra Kitti
Michael \& Jackie Lambert
Samantha Lasry
Leslie Lishon
Malcolm Hewitt Wiener
Foundation
The New York Community Trust -
Lise Strickler \& Mark Gallogly
Charitable Fund
The Nommontu Foundation
Brian Paes-Braga
Kerry Propper
Duco Sickinghe
Nina K. Solarz
Clayton E. Swisher
Enzo Viscusi

AMBASSADOR COUNCIL

Rising stars from diverse fields who contribute their talents and expertise to support Crisis Group's mission.

$\begin{array}{lll}\text { Amy Benziger } & \text { Lindsay Iversen } & \text { Nidhi Sinha } \\ \text { Tripp Callan } & \text { Azim Jamal } & \text { Chloe Squires } \\ \text { Kivanc Cubukcu } & \text { Arohi Jain } & \text { Leeanne Su } \\ \text { Matthew Devlin } & \text { Christopher Louney } & \text { Bobbi Thomason } \\ \text { Victoria Ergolavou } & \text { Matthew Magenheim } & \text { AJ Twombly } \\ \text { Noa Gafni } & \text { Madison Malloch-Brown } & \text { Dillon Twombly } \\ \text { Christina Bache } & \text { Megan McGill } & \text { Annie Verderosa } \\ \text { Lynda Hammes } & \text { Hamesh Mehta } & \text { Zachary Watling } \\ \text { Jason Hesse } & \text { Tara Opalinski } & \text { Grant Webster } \\ \text { Dalí ten Hove } & \text { Perfecto Sanchez } & \end{array}$

\section{SENIOR ADVISERS}

Former Board Members who maintain an association with Crisis Group, and whose advice and support are called on (to the extent consistent with any other office they may be holding at the time).

$\begin{array}{ll}\text { Martti Ahtisaari } & \text { Naresh Chandra } \\ \text { Chairman Emeritus } & \text { Eugene Chien } \\ \text { George Mitchell } & \text { Joaquim Alberto Chissano } \\ \text { Chairman Emeritus } & \text { Victor Chu } \\ \text { Gareth Evans } & \text { Mong Joon Chung } \\ \text { President Emeritus } & \text { Pat Cox } \\ \text { Kenneth Adelman } & \text { Gianfranco Dell'Alba } \\ \text { Adnan Abu-Odeh } & \text { Jacques Delors } \\ \text { HRH Prince Turki al-Faisal } & \text { Alain Destexhe } \\ \text { Óscar Arias } & \text { Mou-Shih Ding } \\ \text { Ersin Arıŏlu } & \text { Uffe Ellemann-Jensen } \\ \text { Richard Armitage } & \text { Gernot Erler } \\ \text { Diego Arria } & \text { Marika Fahlén } \\ \text { Zainab Bangura } & \text { Stanley Fischer } \\ \text { Shlomo Ben-Ami } & \text { Carla Hills } \\ \text { Christoph Bertram } & \text { Swanee Hunt } \\ \text { Alan Blinken } & \text { Aleksander Kwasniewski } \\ \text { Lakhdar Brahimi } & \text { Todung Mulya Lubis } \\ \text { Kim Campbell } & \text { Allan J. MacEachen } \\ \text { Jorge Castañeda } & \end{array}$

Graça Machel Jessica T. Mathews Barbara McDougall Matthew McHugh Miklós Németh Christine Ockrent Timothy Ong Olara Otunnu Lord (Christopher) Patten Victor Pinchuk Surin Pitsuwan Fidel V. Ramos 